\title{
短期データに基づくコンクリートの乾燥収縮ひずみ予測に関する研究 PREDICTION OF DRYING SHRINKAGE STRAIN OF CONCRETE FROM SHORT-TERM TESTS
}

\author{
今 本 啓一*, 石井 寿美江**, 閑 田徹志***, 百 瀬 晴 基****, 藤 森 啓 祐***** \\ Keiichi IMAMOTO, Sumie ISHII, Tetsushi KANDA, \\ Haruki MOMOSE and Keisuke FUJIMORI
}

\begin{abstract}
This paper deals with predictions of drying shrinkage strain of concrete from short-term tests. Two kinds of prediction methods are presented in this study; the simplified method and the extrapolation method proposed by $R$. P.Ojdrovic and authors, respectively. The ultimate shrinkage of concrete can be predicted with one-point data in the short-term tests by the former method and with the extrapolation of continuous data by the latter one. The effectiveness of these methods was verified with drying shrinkage data accumulated in Japan. The test results showed that both methods, which use the shrinkage data up to 21 days, successfully evaluated the long-term shrinkage strains of concretes. Furthermore, the extrapolation method had higher prediction accuracy than the simplified method especially in the case of the gradual development of shrinkage strains.
\end{abstract}

Keywords : drying shrinkage, prediction, short-term tests, ultimate shrinkage strain, extrapolation 収縮ひずみ；短期データ，予測，外挿，CEB-FIP1990

1. はじめに

コンクリートの収縮ひび割れ制御設計において，収縮ひずみの予 測はその要諦をなす。収縮ひずみ評価の最も一般的で確実な方法と して, 最終的な評価に 6 ケ月を要する JIS A 6204 に基づく評価方法 があげられるが，この方法が眼前の構造物を対象としたひひ割れ制 御手法を立案する上で実用的でないことから，各種の予測方法や迅 速評価方法1が提案されている。本論は，主として乾燥による収縮ひ ずみを対象として，提案する収縮ひずみ予測方法の適用性を検証し た結果と課題について述べる。

\section{2. 既往の予測モデルと本研究の位量づけ}

収縮ひずみ予測の研究は古くより行われており，1990年に，椿 2) によって総括的なレビューがなされている。収縮ひずみを予測する 経験則的な方法として，調合・環境・部材条件に基づく各種の算定 式がその簡便さから広く用いられており，これらは阪田 ${ }^{3)}$, 後藤 4) らによってレビューされている。Branson占)によって提案された収縮 ひずみ予測式は，上記の調合・環境・部材条件に加えてコンクリー トのコンシステンシーをも考虑するものであり，ACI209Code6)とし て採用され現在に至っている。CEB-FIP Model Code707)，788)を引
き継ぐ CEB-FIP Model Code909)は，圧縮強度・部材寸法・環境湿度 を予測式の主要因としており, 比較的設計者に馿染みやすい形式と なっている。阪田らは 10)自身の実験によって集積したデータを中心

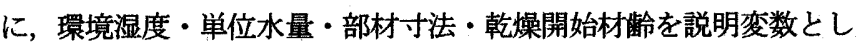
た回帰モデルによって予測式を構築した。さらに国内で実施された 多数のデータも集積し，これに基づいて適用範囲を高強度域に拡張 した予測式も提案した 11)。これらは現行の土木学会標準示方書 12)に 取り入れられている。その他にも多くの実験式が提案されており， これらの多くは文献 13 において概観できる。

一方, コンクリートの収縮は各構成材料の収縮量と構成比のバラ ンスによって決定されるとの考えから, 複合モデルと呼ばれる予測 式も提案されている。大野 ${ }^{14)}$ の並列 2 相モデル, Pickett15) の球殼モ デル, Hobbs ${ }^{16)}$ )代数モデルなど 1970 年代までの総括的なレビュー

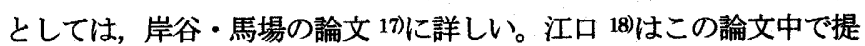
案された馬場式を基に，セメントペーストの収縮ひずみ・ヤング係 数を段階的にコンクリートに拡張した予測式を提案している。各構 成材料の物性を陽に評価できるこのモデルでは，骨材・マトリクスペ 一スト間の遷移領域の評価の必要性が顕在化するが, 清原ら 19)はこ の影響をセメントペースト単味の収縮ひずみに乗じる実験定数とし

\footnotetext{
本論は，文献33）,37)に新たな知見と考察を加えて再構成したものである。

* 足利工業大学工学部建築学科 助教授・博士 (工学)

** 足利工業大学工学部建築学科 研究生

*** 鹿島技術研究所建築生産グループ 上席研究員・Ph. D.

**** 鹿島技術研究所建築生産グループ 研究貝

$* * * *$ 鹿島建設㑣関東支店
}

Assoc. Prof., Department of Architecture, Ashikaga Institute of Technology, Dr. Eng.

Research Engineer, Department of Architecture, Ashikaga Institute of Technology Supervisory Research Engineer, Kajima Technical Research Institute, Ph. D.

Research Engineer, Kajima Technical Research Institute

Kajima Corporation, Kanto Branch 
て評価する手法を採用している。

水和反応モデルのアウトプットとして得られる硬化体の細孔構造

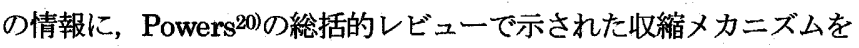
選択的に加味してこれを駆動力とし, 硬化体剛性との力学的なバラ ンスによってコンクリートの収縮ひずみを表現する微視的モデルも 提案されている。友澤 21)によって提案された水和モデルに基づく丸 山 22)の研究, K van Breugel23)の水和モデル” HYMOSTRUC” に

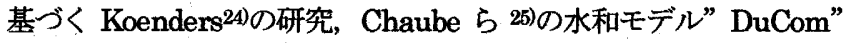
と下村 26)の力学モデルに基づく石田ら 27)の研究があげられる。

数值解析による予測精度は, 一般に JS などの標準的な試験方法 によって得られた值を参照して評価される。上述した経験則的方法 ではその 95\%信頼限界幅は概ね土45\%になることが示されている9)。 複合モデルではその精度が相対的に向上することが報告されている 28)が, 各構成材料の物性值を合理的に得ることが課題として残されて いる。一方, 微視的予測方法は, 現時点では萌芽的であり, 眼前の 収縮ひび割れ制御対策として実用に供するには今しばらくの時間を 要すると考える。

以上を踏まえ, 本研究ではコンクリートの短期データに基づく予 測方法を提案する。短期データに基づく長期ひずみの予測の有効性 は, Z.P.Bazant ${ }^{29)}$ によっても指摘されており, J.J. Brooks ら 30)によ って材㱓 7 および 28 日の測定值より 365 日の収縮ひずみを予測する ための倍率について検討がなされている。Brooks らによる方法を包 含した形で, R.P. Ojdrovic ら 31) によって任意材路令の值を用いた予測 方法とその検証が示されている。この方法は簡易法として後述する。 本論は，国内で収集したデータに基づいてこの简易法の適用性を検 討するとともに，さらにこの簡易法を拡張した外挿法を提案し，そ の妥当性と問題点を検証した結果について述い゙るものである。

なお，本研究はあくまで標準的な環境下において収縮ひずみの平 均值を求める確定論的な予測手法について論じるものであり, 乾湿 繰り返し環境下の収縮ひずみや予測值の標淮偏差の取り扱いについ ては今後の課題として本論では対象外とすることを予め記述する。 実測されたデー夕を基に予測值を逐次に修正する統計的手法として ベイズの定理の活用 32). 33)があるが，この方法は，標準的な環境下の 測定では，数回の修正によって，実質的に測定值を用いることにな ること 33)から，本論においては検討対象とする意義が希薄であり， ここでは触れない。

\section{3. 本研究での検討内容}

本論で検討に用いる予測式として CEB - FIP Model Code 19909）(以下，CEB 式）を取り上げる。この理由は，本式が時間 項に部材寸法を考虑できる構成式となっている点にある。時間項 に部材寸法を考虑しない場合，その収縮ひずみの時間変化を精度 よく追跡できないことが文献 ${ }^{34)}$ においても指摘されており, 後者 の方法の今後の多様な部材寸法への適用性を鑑み, 本論では CEB 式を検討対象とした。

\section{1 调合条件に基づく予測方法(CEB 式)}

この予測式は次の通りである。

$$
\varepsilon_{s h}\left(t, t_{0}\right)=\varepsilon_{s h \infty} \cdot \beta_{s}\left(t-t_{0}\right)
$$

$$
\begin{aligned}
& \beta_{s}\left(t-t_{0}\right)=\left[\left(t-t_{0}\right) /\left(0.035 D^{2}+\left(t-t_{0}\right)\right)\right]^{0.5} \\
& \varepsilon_{\mathrm{sh}}\left(\mathrm{t}, \mathrm{t}_{0}\right) \text { ： 乾燥收縮ひずみ } \\
& \varepsilon \mathrm{sh}_{\infty} \text { ： 乾煴収縮ひずみの最終值 } \\
& \beta_{\mathrm{s}}\left(\mathrm{t} \cdot \mathrm{t}_{0}\right) \quad \text { ： 乾燥収縮ひずみ経時変化特性を表す項 } \\
& \mathrm{t} \text { : 材龄 (日) } \\
& t_{0} \text { : 乾㷄開始材秢 (日) } \\
& \text { D ： 部材の仮想厚さ } \left.=2 \mathbf{A}_{\mathbf{c}} / \mathbf{u} （ \mathrm{~mm}\right) \\
& \mathrm{A}_{\mathrm{c}} \text { : 部材の断面積 }\left(\operatorname{mm}^{2}\right) \\
& \mathrm{u} \text { ：外気に接する部分の周長 }(\mathrm{mm})
\end{aligned}
$$

\section{2 短期データに基すくく予測方法}

1) 簡易法

P.Ojdrovic ${ }^{31)}$ にって提案された手法である。任意の材令にお けるデータを基に最終値（算定最終值）を逆算し、調合条件等に 依存しないコンクリートの乾燥収縮予測方法を提案している。こ こでは CEB 式をベースとした予測を行う。手順は以下の通りで ある。

t=ti-toにおいて，(1)式より乾燥収縮の最終値は,

$$
\varepsilon_{\text {shoo }}=\varepsilon_{s h}\left(t_{i}, t_{0}\right) / \beta_{s}\left(t_{i}-t_{0}\right)
$$

と表すことができる。これを(1)式に代入し，

$$
\varepsilon_{s h}\left(t, t_{0}\right)=\varepsilon_{s h}\left(t_{i}, t_{0}\right) / \beta_{s}\left(t_{i}-t_{0}\right) \cdot \beta_{s}\left(t-t_{0}\right) \cdot(3)
$$

として，長期的なひずみを予測する。石井 35)は JIS 法によって測 定された国内の多数のデータを対象に本手法の適用性を検討し， $\mathrm{t}_{\mathrm{i}}{ }^{-} \mathrm{t}_{\mathrm{o}}=\mathbf{2 8}$ であれば長期の乾燥収縮ひずみを精度良く推定できるこ とを示している。本手法を簡易法と定義し，ここでは著者らによ つて経時的に計測された結果を対象として，より短期のデータ $t_{i}$ の適用性について検討を行う。

2) 外挿法

前述の簡易法は，言い換えれば，該当する短期測定における最 遅データのみを用いて予測を行うものである。本研究であらたな 方法として外挿法を提案する。この方法は当該短期データ全てを 用いて収縮ひずみの最終值を外挿推定し，コンクリートの乾燥収 縮値の予測を目論むものである。これは，以下のステップに基づ いて実施される。

ステップ 1 : 当該短期データの各乾燥後材齢について乾燥収縮最 終值を(2)式により算定する（算定最終值 : 図 1 参照)。ここでは 算定に用いる式は CEB 式とし，算定材龄は 1 日刻みとする。 ステップ 2 : 各材歯に対応する算定最終值が何らかの值(予測最終 值に漸近すると仮定して両者の関係を図 2 に示す双曲線により 最小自乗近似し，予測最終值を得る。本研究の範囲内では若材歯 時ほど最終值を小さく評価する傾向を模式化しているが, これは 後述する実験の結果を踏まえたものである。この傾向が一般的な ものか否かは今後の検討課題であるが, 短期データから乾燥収縮 ひずみを予測する場合，若材路時ほど精度が落ち，用いる材龄が 長くなるほど精度が上がることは半ば自明である。この様相を定 性的に示したものがステップ2であり，ある時点の予測最終值が 一定の值に漸近すると仮定し，その最終值を具体的に求める一手 
法として双曲線式近似を，本研究では用いた。

ステップ 3 : 予測最終值に基づく曲線において予測值と当該短期 データの最遅材㱓の実測值に生じた差を(4)式により補正する (図 3)。

$$
\varepsilon_{s h}\left(t, t_{0}\right)=\frac{1}{b} \cdot \beta_{s}\left(t-t_{0}\right)-\left\{\frac{1}{b} \cdot \beta_{s}\left(t_{i}-t_{0}\right)-\varepsilon_{s h}\left(t_{i}, t_{0}\right)\right\}
$$

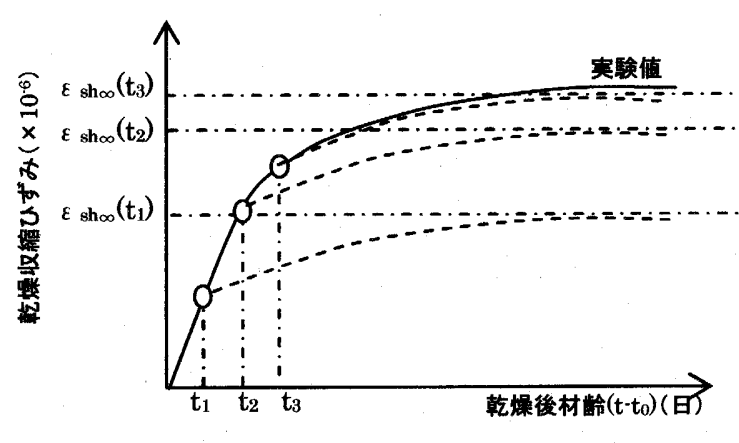

図 1 ステップ1の模式図

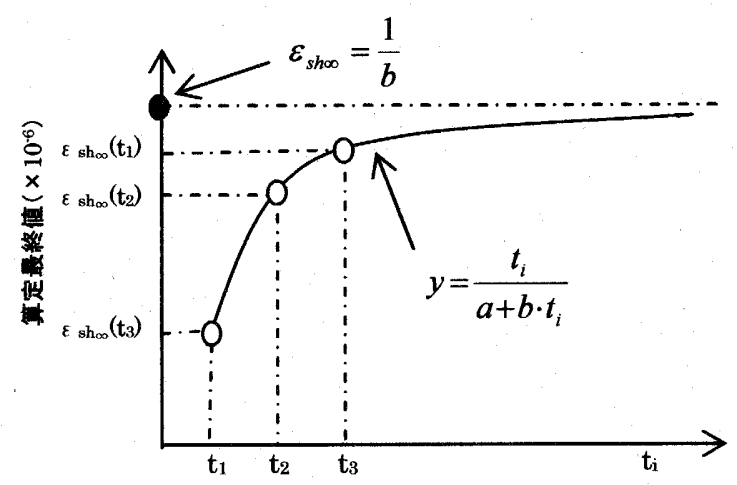

図 2 ステップ 2 の模式図

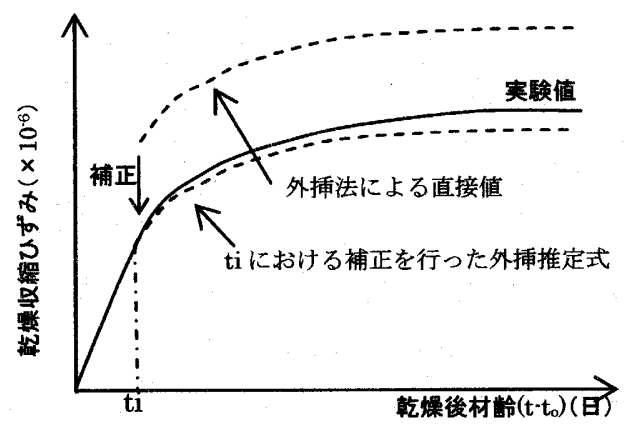

図 3 ステップ3の模式図

\section{4. 各予測方法の適合性の検証}

本論で対象とする各予測方法の適用性を検証するための実験 概要を以下に示す。

\section{1 コンクリートの調合条件}

本室内実験で使用した調合条件を表 1 に示す。セメントは全て 普通ポルトランドセメントとした。

\section{2 乾燥収縮ひずみ}

試験体は $\phi 10 \times 20 \mathrm{~cm}$ とし, 打設後 2 日で脱型し, 7 日間水中
養生とした。乾燥環境は $20 \pm 1^{\circ} \mathrm{C}, 60 \pm 5 \%$ R.H.であり, コンク リートのひずみの測定には埋込みゲージを使用し， 3 体の平均值 を以降の検討に用いた。乾燥収縮の測定結果を図 4 に示す。材龄 180 日におけるコンクリートの乾燥収縮ひずみは, 約 500〜1100 $\times 10^{-6}$ と広範囲に分布している。

\section{表 1 調合条件}

\begin{tabular}{|c|c|c|c|c|c|c|}
\hline \multirow{2}{*}{ 工場名 } & \multirow{2}{*}{$\begin{array}{l}\text { W/C } \\
(\%)\end{array}$} & \multirow{2}{*}{$\begin{array}{l}\text { S/a } \\
(\%)\end{array}$} & \multirow{2}{*}{$\underset{\left(\mathrm{kg} / \mathrm{m}^{3}\right)}{W}$} & \multicolumn{3}{|c|}{ 使用骨材及び混和材料 } \\
\hline & & & & 細骨材 & 粗骨材 & 混和剂 \\
\hline \multirow[b]{2}{*}{ A } & $\begin{array}{l}53.0 \\
50.0\end{array}$ & 45.7 & $\frac{183}{184}$ & 陸砂 & 石灰岩 & $\mathrm{AE}$ 減水剈 \\
\hline & 48.0 & 45.6 & 170 & 陸砂 & 石灰岩 & $\begin{array}{l}\text { 高性能 } \\
\text { AE 減水剤 }\end{array}$ \\
\hline \multirow{2}{*}{ B } & $\begin{array}{l}54.5 \\
50.0\end{array}$ & 4 & $\frac{180}{184}$ & 陸砂 & 砂岩 & $\mathrm{AE}$ 減水剂 \\
\hline & 48.5 & 46.7 & 170 & 陸砂 & 砂岩 & $\begin{array}{l}\text { 高性能 } \\
\mathrm{AE} \text { 減水剂 }\end{array}$ \\
\hline C & $\begin{array}{l}53.0 \\
50.0 \\
47.0\end{array}$ & $\begin{array}{l}49.2 \\
47.6 \\
45.7\end{array}$ & $\begin{array}{l}180 \\
182 \\
184\end{array}$ & 陸砂 & 石灰岩 & $\mathrm{AE}$ 減水剂 \\
\hline D & 45.4 & $\mathbf{4 4 . 5}$ & 172 & 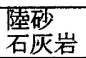 & 砂岩 & $\begin{array}{l}\text { 高性能 } \\
\mathrm{AE} \text { 減水郕 }\end{array}$ \\
\hline $\mathbf{E}$ & 50.0 & 45.0 & 172 & $\begin{array}{l}\text { 陸砂 } \\
\text { 砕砂 }\end{array}$ & 雲母花岡岩 & $\mathrm{AE}$ 减水剂 \\
\hline $\mathbf{F}$ & 57.9 & 47.5 & 182 & 砂岩 & $\begin{array}{l}\text { 砂罘 } \\
\text { 石炭 }\end{array}$ & $\mathrm{AE}$ 減水剂 \\
\hline G & $\mathbf{5 7 . 0}$ & 46.4 & 190 & $\begin{array}{l}\text { गा砂 } \\
\text { 流紋岩 }\end{array}$ & 流紋岩 & $\mathrm{AE}$ 堿水剂 \\
\hline$\overline{\mathrm{H}}$ & 53.0 & $=$ & 171 & 陸砂 & 石灰碞 & AE 減水斎 \\
\hline I & 50.1 & 44.1 & 171 & $\begin{array}{l}\text { 山砂 } \\
\text { 海砂 }\end{array}$ & $\begin{array}{l}\text { 硬質砂罘 } \\
\text { 石岩 }\end{array}$ & $\mathrm{AE}$ 減水剂 \\
\hline $\mathrm{J}$ & 53.9 & 47.0 & 180 & 安山罘 & 硬䓄础岩 & AE 減水剂 \\
\hline $\bar{K}$ & 54.0 & 43.2 & 177 & 海砂 & 砂岩 & AE 減水剂 \\
\hline $\bar{L}$ & 51.0 & 40.4 & 166 & 海砂 & 陸砂利 & AE 減水剂 \\
\hline $\mathbf{M}$ & 53.0 & 47.3 & 183 & 臸岩 & 珪岩 & $\mathrm{AE}$ 減水剂 \\
\hline
\end{tabular}
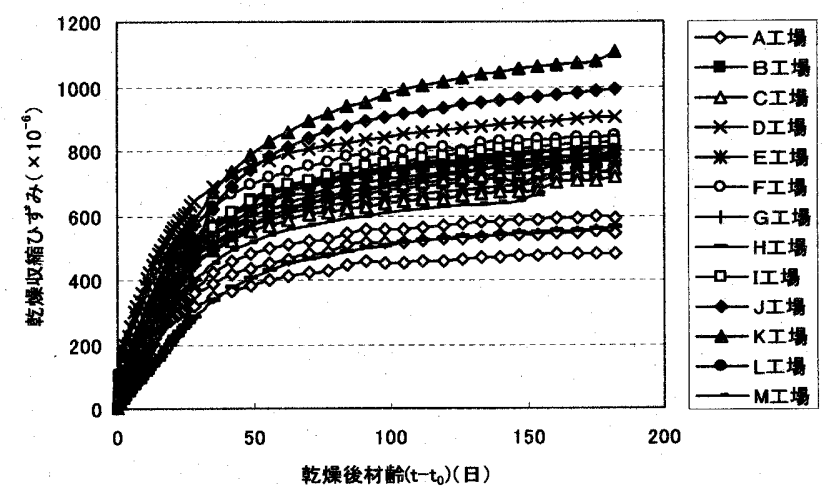

図 4 乾燥収縮ひずみの変化

\section{5. 各予測方法の適合性の評価}

\section{1 調合条件に基づく予測式}

(1)式による計算值と実験値の比較を図 5 に示す。

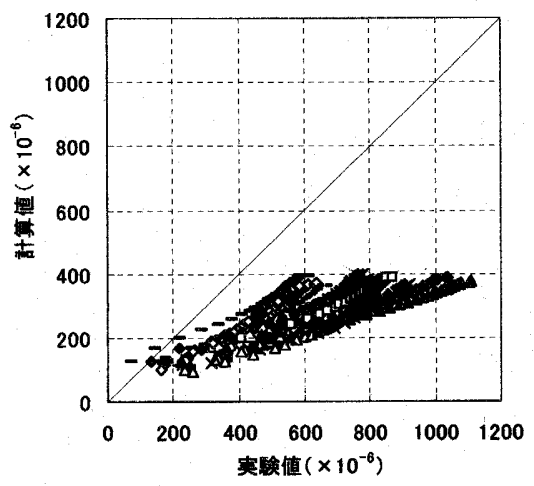

図 5 実験値と計算値の比較 
図より，CEB 式の計算值は実験値に対して全体的に過小評価す る傾向にある。この傾向は以前より指摘のなされる所である 36 が，本実験においても同様の結果となっている。

\section{2 ：短期データに基つく予測方法}

本研究は, 算定に用いる短期材龄 $\left(\mathrm{t}_{\mathrm{i}}-\mathrm{t}_{\mathrm{o}}\right)$ として, 7, 14, 21, 28 日 において検討を行った。简易法による計算值と実験值の比較及び 外挿法による計算值と実験值の比較を図 6 に示す。図 6,7 より, 調合条件に基づく予測方法の結果（図 5 参照）と比較すると，そ れぞれの予測式の計算值は, 概ね実験值を追跡できている。また,
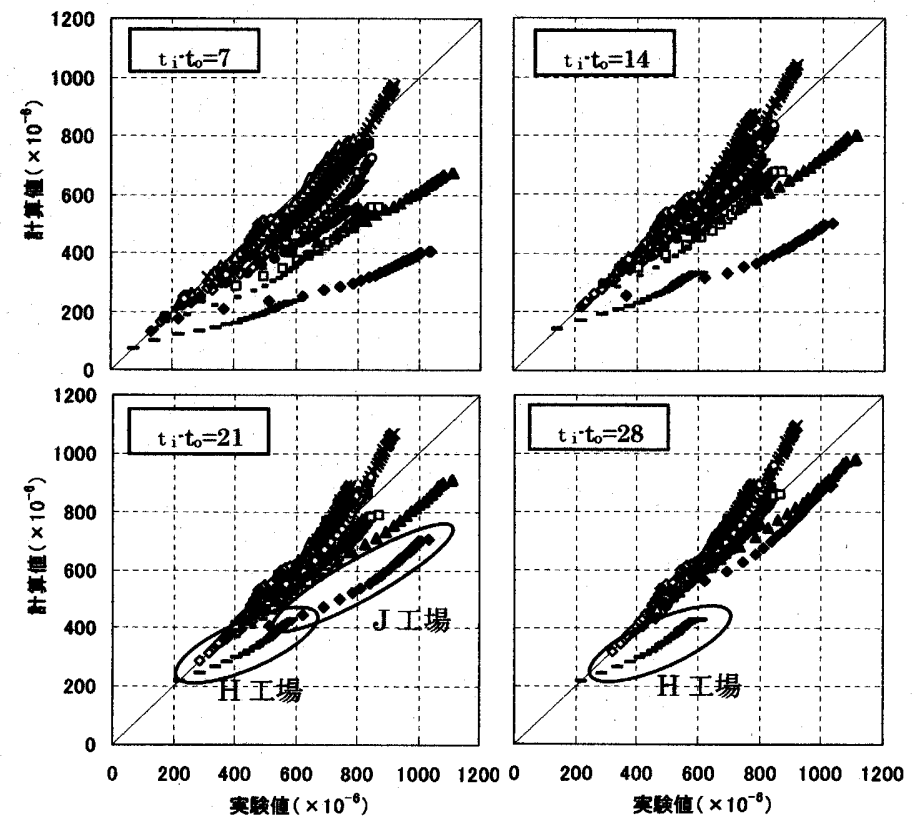

（a）简易法
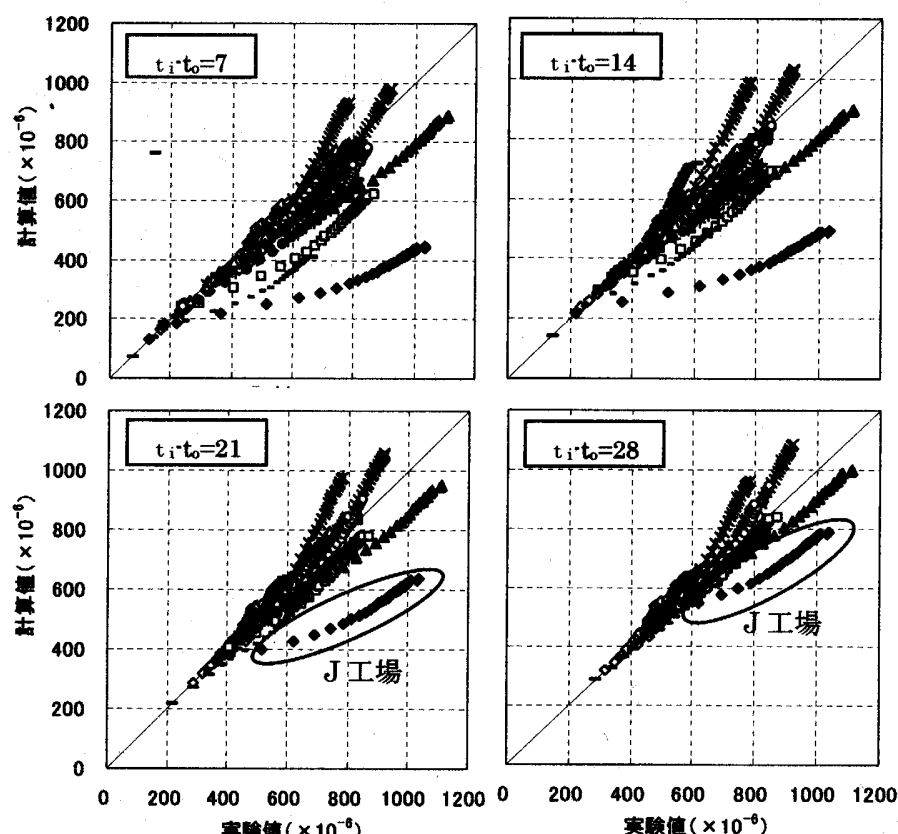

(b) 外插法

\begin{tabular}{|c|c|c|c|c|}
\hline$\approx$ AI坦 & $\rightarrow-B I t$ & $\rightarrow-C I \pm$ & $\rightarrow$ DI场 & －E工埕 \\
\hline -FI畦 & -GI场 & 一H工场 & $\rightarrow$-I工坦 & -ーJ工場 \\
\hline
\end{tabular}

图 6 实験值と㖕算值の比較
いずれの式も， $\mathrm{t}_{\mathrm{i}}-\mathrm{t}_{\mathrm{o}}$ が長くなるにつれ，実験值と計算値の適合性 が高くなり， $t_{i}-t_{0}$ が 21 日以降であれば，予測精度は概ね良好で ある。しかし简易法（図 6(a)）においてはH工場やJ工場のよう に，また外挿法(図 6(b))においては J工場のように予測精度が相 対的に劣るケースも見受けられる。この点に関して考察を加える。

簡易法，外挿法のいずれにおいても精度良くひずみを予测でき た C 工場の, (3)式による最終值の変化を例として図 7 に示す。こ の場合, 乾燥後材齢 5 日以降では算定最終值は概小安定しており, 結果として，いずれの予測方法によっても概ね精度の良い結果を 導くことができている。一方， H 工場の各材跉における算定最終 値の変化を図 8 に示す。図に見られるように, 乾燥後材齢 28 日 の間において，予測最終值は収束する傾向を見せながらも増進し 続けている。これは, 図 9 に示すように, コンクリートの収縮ひ ずみの進行が相対的に緩慢なために起こる結果であり，このよう なケースにおいては簡易法の適用は困難と判断される。一方，当 該短期材齢の全ての情報を活用する外挿法は，このようなケース においては有効であり, 図 6(b)に示されるように, 良好な精度で の予測が可能となっている。

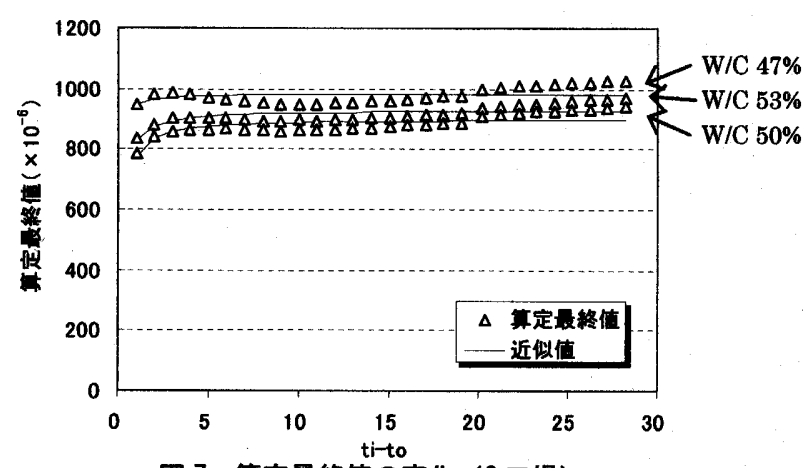

图 7 算定最終值の変化（C工場）

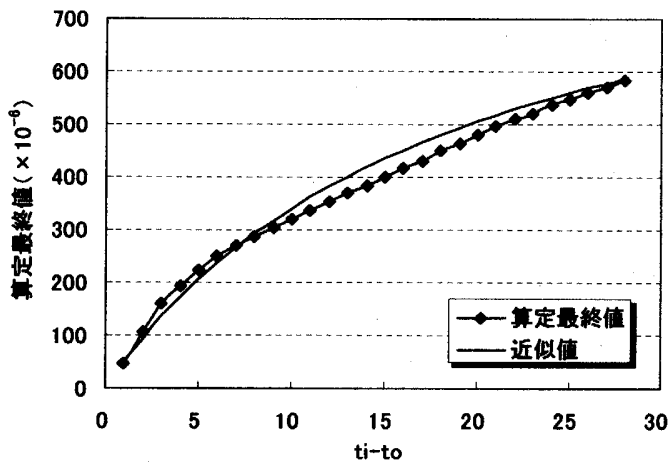

図 8 算定最終值の変化 (H工场)

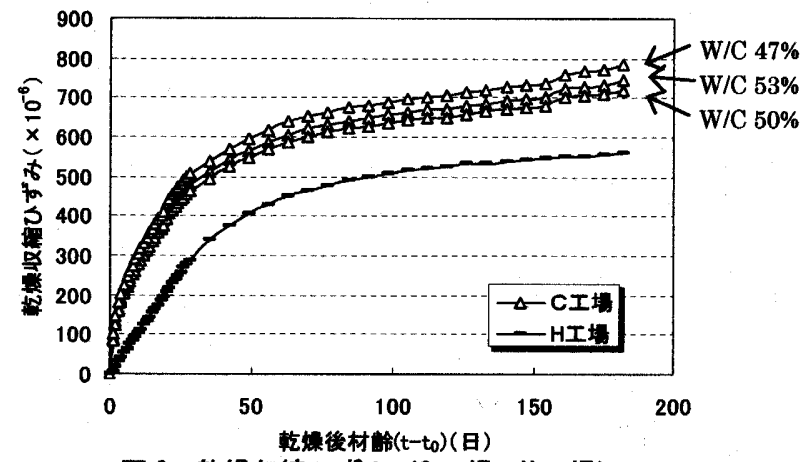

图 9 乾㷄収縮ひずみ（C工堣，H工場） 
J工場の各材齢における算定最終值の変化を図 10 に示す。この ケースは, コンクリートの収縮ひずみが乾燥後材龄 10 日前後を 境に異なる進展傾向(変曲点)を示したものである (図 11)。実験に 用いた 3 本の試験体全てがこのような傾向を示したことと, 別途 採取した同プラントの現場打設コンクリートの乾燥収縮ひずみ測 定結果も同様の挙動を示したことから, 本研究においてはこの傾 向が再現性のあるものと判断した。詳細な原因の究明は今後の課 題であるが，このようなケースにおいては直接的に本論で提案す る手法を適用することは困難であり，算定最終值の収束傾向を見 極めた上で，簡易法，外挿法のいずれかを適用する必要がある。 次善の策としての外挿法の修正結果（材㱓 28 日を通過する）を 図 10,12 に示す。図 13 においては，上記の修正を施した結果も

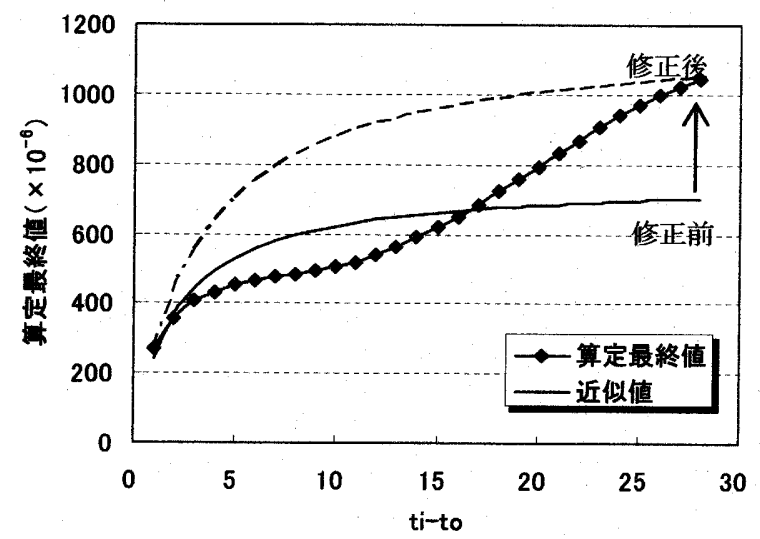

図 10 算定最終値の变化 (J工場)

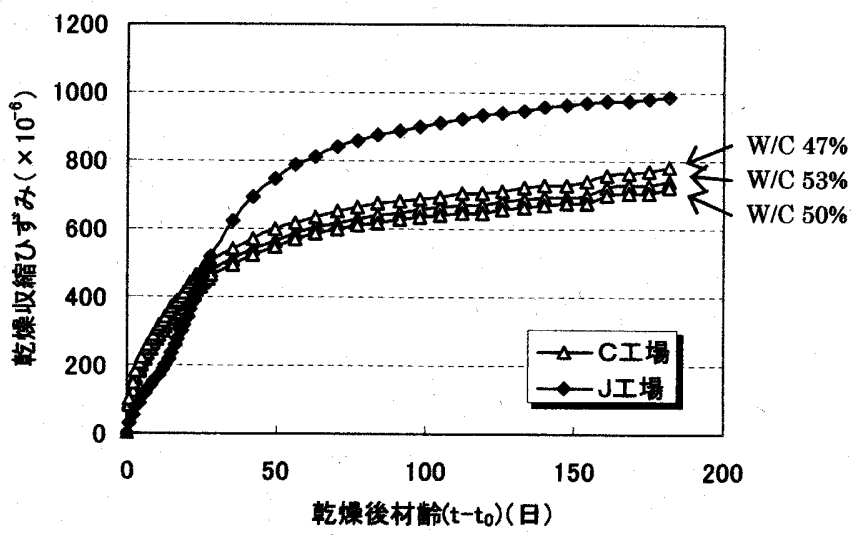

图 11 乾燥収編ひずみ（C工場，J工場）

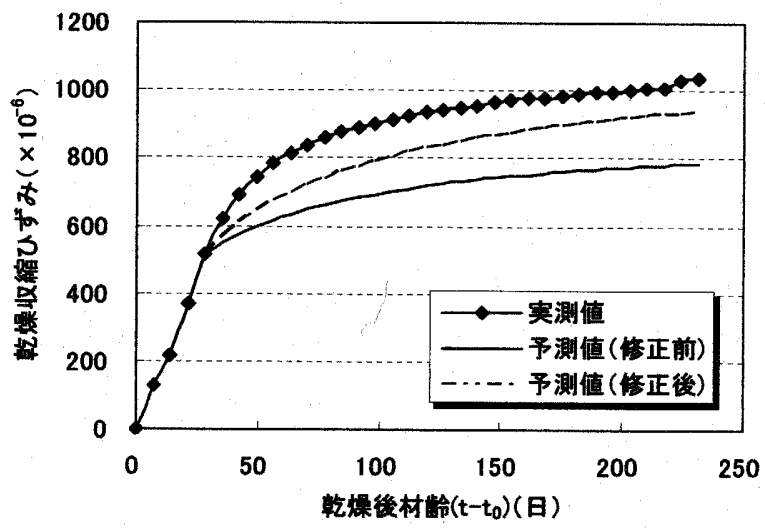

図 12 乾燥収緛ひずみ（Jエ場）
あわせて掲載しているが，本実験結果を対象とした場合，外挿法 によれば，乾燥後材齢 28 日で概ね $\pm 15 \%$ 程度の誤差で実測値を 追跡できている。

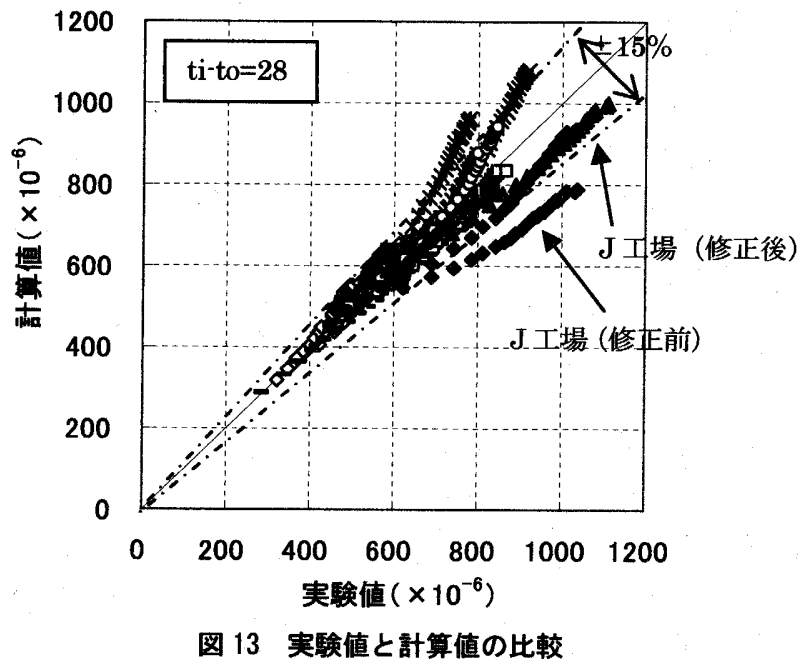

6. まとめ

調合・部材・環境条件に基づく簡便な経験的予測方法と, 最終 的な評価に 6 ケ月を要する実測試験の中庸的な方法として, 短期 データに基づく収縮ひずみの予測方法について検討を行った。本 論で得られた知見を以下に示す。

1）算定に用いる短期データの集積期間が長いほど予測精度は 高まる。乾燥後材齢 21 日程度以降であれば，予測精度は概 ね良好となる可能性が高い。

2）簡易法による算定最終値が概ね安定していることを見極め ることにより，簡易法，外挿法のいずれによっても概ね良い 精度で収縮ひずみを予測することが可能である。

3）コンクリートの収縮ひずみが緩やかな進展傾向を有する場 合，すなわち簡易法による算定最終値が増進し続ける場合は, 外挿法による予測値が比較的良い精度を与える。

4）簡易法による算定最終值の変化が変曲点を有する場合, 簡易 法・外挿法の直接的な適用は困難であり, 算定最終値の収束 傾向を見極める必要がある。このような場合の対応は今後の 課題であるが，本論において次善の策としての対応方法を示 し，その適用性を検証した。

\section{参考文献}

1）小島正朗他：コンクリートの迅速乾燥収縮試験法の開発，コンクリート '工学年次論文集, Vol.24, No.1, pp.417-422, 2002.

2）椿龍载 : コンクリートのクリープと乾燥収縮の予測手法の現状, 土木学 会論文集，第 414 号/V-2，pp.23-31，1990.2

3）阪田憲次：コンクリートの乾燥収縮およびクリープの予測，コンクリー 卜工学, Vol.31, No.2, pp.5-14, 1993.2

4) 後藤和正 : コンクリートの乾燥收縮予測式に関する最近の研究, コンク リート工学, Vol.33, No.4, pp.62-67, 1995.4

5) D.E. Branson and M.L. Christiason, "Time Dependent Concrete Properties Related to Design-Strength and Elastic Properties, Creep, and Shrinkage", 
Designing for Effect of Creep, Shrinkage, and Temperature in Concrete Structures, ACI SP-27-13, pp.257-277, American Concrete Institute, Detroit, 1971.

6) ACI Committee 209, Prediction of Crecp, Shrinkage, and Temperature Effects in Concrete Structures (ACI 209-82), 1982.

7) CEB-FIP, International Recommendation for the Design and Construction of Concrete Structures, Cement and Concrete Association, London, 1970.

8) CEB-FIP, Structural Effects of Time-Dependent Behavior of Concrete, George Publishing Company Saint-Saphorin, Switzerland, 1984.

9) CEB-FIP Model Code1990, Thomas Telford

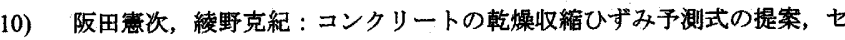
メント技術大会講演集, No.43, pp.338-343， 1989.

11) Kenji SAKATA, et.al,"Rediction Equations of Creep and Drying Shrinkage for Wide-Ranged Strength Concrete", Creep, Shrinkage and Durability Mechanics of Concrete and Other Quasi-Brittle Materials, pp.753-758, 2001.8

12）士木学会，コンクリート標準示方書 構造性能照查編（平成 12 年度版）

13） 日本建築学会, コンクリートの調合設計指針・同解説

14）大野和男，モルタル及びコンクリートの乾燥収縮と龟裂防止に関する研 究, 北海道大学工学部研究報告, No.9, pp.49-110, 1953.

15) G. Pickett, " Effect of Aggregate on Shrinkage of Concrete and Hypothesis Concerning Shrinkage", Journal of the ACI, pp.581-590,1956.1

16) D.W. Hobbs, The Dependent of the Bulk Modulus, Young's Modulus, Creep Shrinkage and Thermal Expansion of Concrete upon Aggregate Volume Concentration, RILEM Bulletin, Vol.4, No.20. pp.107-114, 1971.

17）岸谷孝一, 馬場明生, 建築材料の乾煤収縮機構, セメント・コンクリー ト, No.346, pp.30-40, 1975.12

18） 江口清, 寺西浩司, 複合モデルを基整としたコンクリートの乾燥収縮予 測式, 日本建築学会構造系論文集, No.557, pp.15-22, 2002.7

19) 清原千鶴, 佐藤嘉昭他, 複合則理論を用いたコンクリートの乾燥収縮ひ ずみの推定, コンクリート工学年次論文集, 第 26 巻, 第 1 号, pp.489-494, 2004 .

20) T.C. Powers, "Mechanisms of Shrinkage and Reversible Creep of Hardened Cement Paste", The Structure of Concrete, Proceedings of an International Conference, pp.319-343, London, Sep.1965

21）友滓史紀，セメントの水和反応モデル，セメント技術年報，XXVIII， pp.53-57, 1974.

22）丸山一平, マイクロメカニクスに基づくコンクリートの時間依存特性, 東京大学学位論文, pp.92-109, 2003.3
23) K. van Breugel, "Numerical Simulation of Hydration and Microstructural Development in Hardening Cement-based Materials (1. Theory)", Cement and Concrete Research, Vol.25, No.2, pp.319-331, 1995.

24) E.A.B. Koenders, et.al, "Numerical Modeling of Autogenous Shrinkage of Hardening Cement Pastes", Cement and Concrete Research, Vol.27, No.10, pp.1489-1499, 1997

25) K. Maekawa, et.al, "Modeling of Concrete Performance", E \& FN SPON, London, Apr., 1999.

26）下村匠, 前川宏一, 微視的機構に基づくコンクリートの教煤収縮モデル， 土木学会論文集, No.520/V-28, pp.35-45, 1995.

27）石田哲也，微細空隙を有する固体の変形，損稘と物所・エネルギーの生 成・移動に関する連成解析システム, 東京大学学位論文, pp.73-87, 1999.3

28）寺西浩司, 佐藤嘉昭, 複合理論に基づくコンクリートの乾㷄收綰予測式 の扗張-3 相モデルへの展開および部材寸法の影綁の考虑-, 日本建築学会 大会学術講演梗概集 A-1 材料施工, pp.605-606, 2005.9

29) Z.P. Bazant, J.K.Kim, "Improved Prediction Model for Time-Dependent Deformation of Concrete: Part 1-Shrinkage", Materials and Structures, 24, pp.327-345, 1991.

30) J.J. Brooks and A.M. Neville, "Estimating Long-term Creep and Shrinkage from Short-term Tests", Magazine of Concrete Research, Vol.27, No.9, pp.3-12, 1975.

31) Rasko P.Ojdrovic and Mehdi S.Zarghamee, "Concrete Creep and Shrinkage Prediction from Shot-Term Tests", ACI Materials Journal, pp169-176, 1996.

32）伊藤学, 龟田弘行訳, 土木・建築のための確率・統計の基磷，丸善， pp.338-345, 1995 .

33）石井寿美江，今本啓一，閑田徹志，百瀨睛基，藤森啓祐 : 短期の実験デ 一タに基づくコンクリートの乾䶂収縮ひずみの予剆，日本建築学会関東 支部研究発表会, pp.37-40, 2005.

34）百瀬暸基他 3 名 : 低熱ポルトランドセメント及ひ彰偯材を用いたコンク リートの膨張収縮挙動に関する研究，コンクリート工学年次論文集，第 26 巻, 第 1 号, pp.495-500, 2004.

35）石井寿美江，今本啓一：短期の奏験データに基づくコンクリートの乾爆 収縮量の予测，日本建築学会学術講演梗概集 (東海), pp115 116, 2003.9.

36）今本啓一，山本俊彦 : 既往の実験データに基づいたコンクリートの乾煏 収縮予測当てはめ式の提案, 日本建築学会構造系論文集, No.552, pp.1-6, 2002.2

37）石井寿美江, 今本啓一, 閑田徾志, 百瀬晴基, 藤森啓祐 : 短期の奏験デ

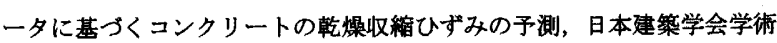
拲演梗概集 A-1 材料施工，pp.607-608，2005. 